\title{
Large scale sex typing of ostriches using DNA extracted from feathers
}

\author{
Wilson Malagó Jr${ }^{1}$, Heitor M Franco ${ }^{1}$, Euclides Matheucci Jr${ }^{2}$, \\ Adriana Medaglia ${ }^{2}$ and Flavio Henrique-Silva*1
}

Address: ${ }^{1}$ Department of Genetics and Evolution - Federal University of São Carlos, Rodovia Washington Luis, Km 235 - CEP: 13565-905, São Carlos, SP, Brazil and 2DNA Consult Genetics and Biotechnology S/C Ltda, Rua Major José Inácio, 1738 - CEP: 13560-160, São Carlos, SP, Brazil

E-mail: Wilson Malagó - wil_zola@yahoo.com.br; Heitor M Franco - heitor_franco@bol.com.br;

Euclides Matheucci - euclidesdna@dnaconsult.com.br; Adriana Medaglia - adriana@dnaconsult.com.br; Flavio Henrique-

Silva* - dfhs@power.ufscar.br

*Corresponding author

Published: I October 2002

BMC Biotechnology 2002, 2:19
Received: 19 June 2002

Accepted: I October 2002

This article is available from: http://www.biomedcentral.com/1472-6750/2/19

(C) 2002 Malagó et al; licensee BioMed Central Ltd. This article is published in Open Access: verbatim copying and redistribution of this article are permitted in all media for any purpose, provided this notice is preserved along with the article's original URL.

\begin{abstract}
Background: Ostrich (Struthio camelus) breeds have been gaining increasing significance around the world. The large-scale sex determination of chicks is an important task in the development of these breeds. To date, two PCR-based methods have been established for ostrich sex typing, neither of them intended for large-scale analyses. Here, we report on a protocol adapted to carry out large-scale gender scoring using DNA obtained from chick feathers.
\end{abstract}

Results: The DNA was extracted using a fast and simple alkaline extraction protocol that provided sufficient template for an early diagnosis. Tests with several primer sets enabled us to determine the best internal control primers associated with the sex-specific primers, avoiding spurious bands. Using DNA extracted from a single bulb and the best set of primers, we applied this protocol to simultaneously sex-type 96 individuals accurately.

Conclusion: We have established a fast, safe, accurate and inexpensive procedure for large-scale sex typing of ostriches using DNA extracted from feathers. This procedure is useful for the gender identification of chicks in the first days of nestling life.

\section{Background}

In many bird species, it is very difficult to distinguish between males and females based on an analysis of their external morphology, especially young birds. Moreover, every discriminating procedure employed should be safe, accurate, fast and inexpensive. Karyotyping may be a good choice for the sex typing of birds but, unfortunately, the low divergence of $\mathrm{Z}$ and $\mathrm{W}$ chromosomes precludes this approach in ostriches $[1,2]$. On the other hand, conventional techniques to identify the sex of ostriches present significant problems: the animals may suffer stress, since they are subjected to invasive procedures such as endoscopy and cloaca touch. Furthermore, the bird's sex can be identified only in the adult stage, and even then only with a low rate of efficiency (in juvenile birds the rate of error may reach up to around $40 \%$ ). In the last few years, two reports described PCR-based methods to sex-type ostriches $[3,4]$. A method by which small PCR bands are produced, was established by [4]. Another method uses sexspecific primers for a larger female fragment associated 


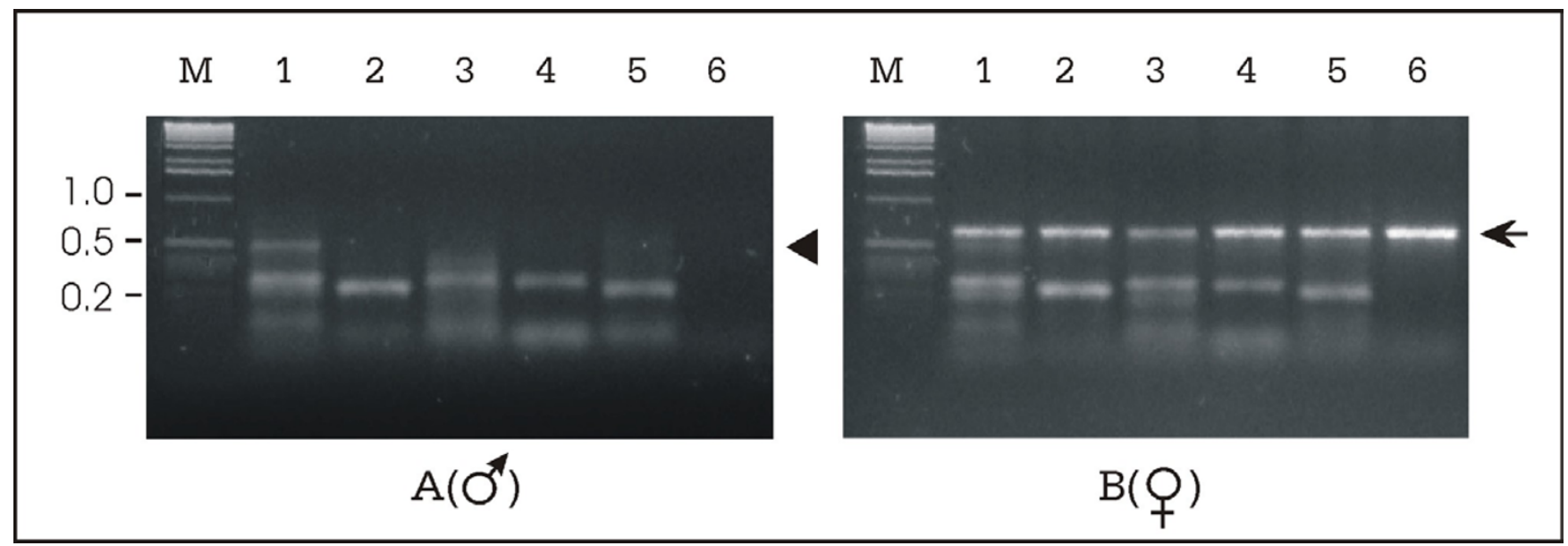

Figure I

Multiplex PCR-based sex-typing tests with specific female and different internal control primer pairs. A: Male samples: $M=1$ Kb Marker (Invitrogen); lane I: SS and LOI4 pairs; lane 2: SS and OSM5 pairs; lane 3: SS and OSM7 pairs; lane 4: SS and VIASOS4 pairs; lane 5: SS and VIAS-OSI 4 pairs; lane 6: only SS pair. The arrowhead indicates an interference band. B: Female samples: $M=$ I Kb Marker (Invitrogen); lane I: SS and LOI4 pairs; lane 2: SS and OSM5 pairs; lane 3: SS and OSM7 pairs; lane 4: SS and VIAS-OS4 pairs; lane 5: SS and VIAS-OSI 4 pairs; lane 6: only SS pair. The arrow indicates female-specific bands.

Table I: Sequences of primer pairs used in multiplex reactions and expected sizes of PCR products

SSI 5'-TCTACACCTAAGGAGTCCCATATT-3' OSM5f 5'-GTGGATCAGTTCAATCCTTGC-3' OSM7f 5'-AGCATACACATGCAGACCCC-3' L0I4a 5'-CCAGTCAGGAGCACCTGTTC-3' VIAS-OS4f 5'-CTCCTGGATGTTCTAGCAGT-3' VIAS-OSI 4 f 5'-CACTTCTCCGAATTTTAAAAGG-3'
SS2 5'-GGTCTACACCTGTTGAAAATCATT-3' OSM5r 5'-GCCCAAGAAAATGATGGAGA-3' OSM7r 5'-TGTTTCCTGCCATTCTGTCA-3' L0I4b 5'-AGAGCAGGGATGACTGTGGC-3' VIAS-OS4r 5'-CTCCTTGTCCAGCCATATAC-3' VIAS-OSI4r 5'-AGGAAGAGATGTGGAGTCCC-3'

\section{$648 \mathrm{bp}$}

232 bp

$215 \mathrm{bp}$

280 bp

$216-268$ bp

$209-245$ bp with internal standard primers in amplification reactions [3]. Both these methods involved the use of DNA extracted from blood and they were not yet adapted for largescale analysis. This paper presents an improved protocol, beginning with DNA extracted from feathers bulbs, which can provide sex-identification in the first days of nestling life. Furthermore, we used different control primers to determine the best sets for sex typing and to avoid any kind of spurious band. Finally, we adapted the procedure for use with 96 wells PCR plates, providing a large-scale method.

\section{Results and Discussion}

The alkaline extraction used in this work provided a total of approximately $1 \mu \mathrm{g}$ of DNA from each feather bulb (final concentration about $5 \mathrm{ng} / \mu \mathrm{l})$, with $2 \mu \mathrm{l}$ used as template in PCR reactions. In our tests, the reactions using specific female primers associated with L014 microssatel- lite primers [3] showed an extra band of approximately 500 bp, which was particularly evident in males (Fig. 1A, lane1). This band may lead to misinterpretations, particularly in large-scale analyses, in which males could be identified as females. When associated with female primers, none of the other control primers produced spurious bands (Fig. 1). However, in comparison with the others, the multiplex reactions carried out with OSM5 primers produced more intense and clear amplification bands (Fig. 1A, lane 2 and Fig. 1B, lane 2). Because the SS/OSM5 set provided the best results, it was selected for large-scale analyses. We used this set of primers to sex-type about 100 individuals and verified $100 \%$ of accuracy, since the reactions were made in triplicate and the animals' sex was confirmed later by conventional techniques. The DNA extraction on 96 well PCR plates worked well, providing sufficient DNA for PCR and taking less then one hour to complete. Using a steel replicator, the DNA was easily 


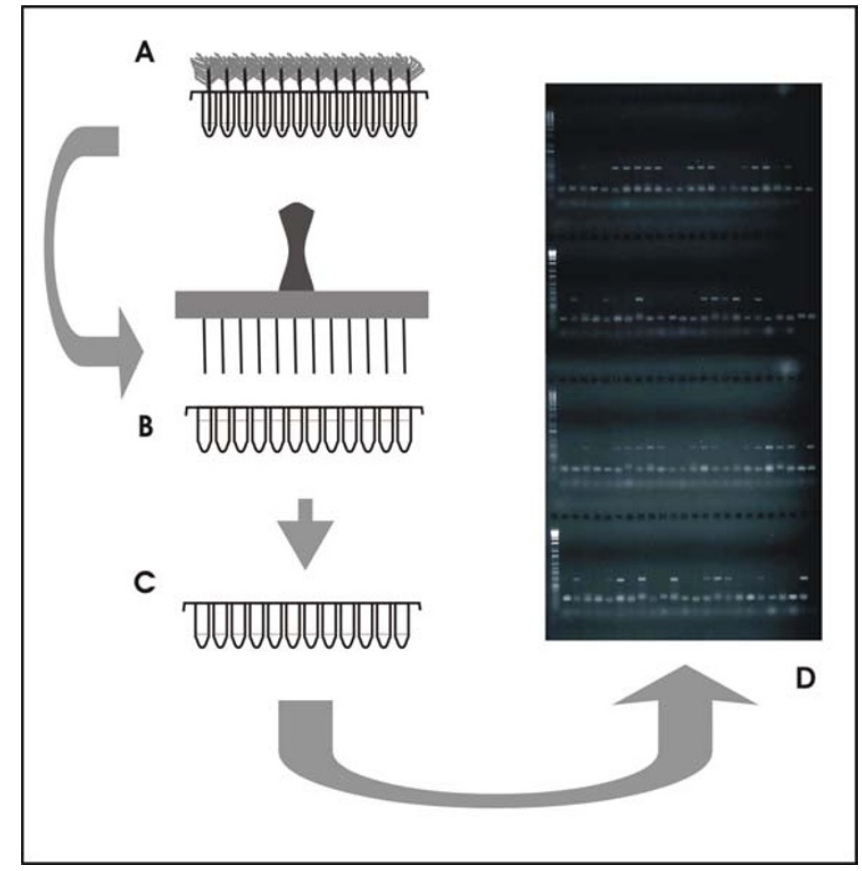

Figure 2

Large-scale sex-typing analysis. A: The feather bulbs were submerged in the extraction solution contained on a 96 well PCR plate. B: After the extraction and neutralisation of the reactions, the template DNAs were transferred with a replicator to a novel 96 well PCR plate on which reaction mix had previously been placed. C: The plate was covered and PCR was then carried out. D: The PCR products were subjected to electrophoresis in an agarose gel to determine the animals' sex.

transferred directly to the PCR plate containing the reaction agents. This approach allows not only large-scale analyses but is also useful to prevent cross contamination in PCR and unintentional exchanges of samples, and can be used for other analyses such as parentage tests and others.

\section{Conclusions}

In this report, we have established a fast, safe, accurate and inexpensive procedure for large-scale sex typing of ostriches using DNA extracted from feathers. The method described here begins with a quick and easy DNA extraction step that dispenses with the use of phenol chloroform. Furthermore, the use of chick feathers provides an early diagnosis that can be adapted for large-scale analyses being useful for the sex identification of chicks in the first days of nestling life.

\section{Methods Animals}

A group of 5-day-old chicks was subjected to sex typing according to [3]. One male and one female individual were selected for the analysis described herein. They were also subsequently sex identified by conventional techniques at 3 months of age. Additional analyses of about 100 individuals were made to verify the reliability and accuracy of the procedure reported herein.

\section{DNA extraction}

The DNA template was obtained by rapid simple alkaline extraction [5] from one feather bulb of each preselected individual. The bulbs were submerged in $20 \mu \mathrm{l}$ of $0.2 \mathrm{~N}$ $\mathrm{NaOH}$ in a $1.5 \mathrm{ml}$ tube and left in a water bath at $75^{\circ} \mathrm{C}$ for 20 minutes. The solution was neutralised by adding 180 $\mu \mathrm{l}$ of a $0.04 \mathrm{M}$ Tris-HCl pH 7.5 solution. For large-scale extraction, the feather bulbs were submerged in wells from a 96 well PCR plate containing $20 \mu \mathrm{l}$ of $0.2 \mathrm{~N} \mathrm{NaOH}$ (Fig. $2 \mathrm{~A})$. The plate was covered with a plastic lid, placed in a PCR machine with the hot lid disabled and the machine set for $75^{\circ} \mathrm{C}, 20 \mathrm{~min}$. (Fig. 2). The neutralisation was then carried out as described above.

\section{PCR}

Specific primers for female fragments SS1 and SS2 [3] (Table 1) were used in each sex-typing PCR reaction. For each tube reaction, one of the standard internal control primer pairs, which amplifies microsatellites regions, was associated with sex specific primers: OSM5 and OSM7 [6]; L014 [7]; VIAS-OS4 and VIAS-OS14 [8] (Table 1). The multiplex PCR reactions were all carried out in a $15 \mu \mathrm{l}$ volume containing $2 \mu \mathrm{l}$ of prepared DNA template (approximately $10 \mathrm{ng}$ of DNA), 3 pmol of each primer, $0.5 \mathrm{U}$ of Taq DNA polymerase (Amershan Biosciences), $10 \mathrm{mM}$ Tris$\mathrm{HCl} \mathrm{pH} 9.0,1.5 \mathrm{mM} \mathrm{MgCl}_{2}, 50 \mathrm{mM} \mathrm{KCl}$, and $37,5 \mu \mathrm{M}$ of each dNTP. For PCR on 96 well plates, $13 \mu \mathrm{l}$ of this reaction mix was first added to the wells and all the different 96 template DNAs were added simultaneously to the reaction, using a steel replicator (Boeco). The PCR protocol was carried out beginning with a heating temperature of $95^{\circ} \mathrm{C}$ for $2 \mathrm{~min}$., followed by 30 cycles consisting of $40 \mathrm{~s}$ at $94^{\circ} \mathrm{C}, 40 \mathrm{~s}$ at $54^{\circ} \mathrm{C}$ and $1 \mathrm{~min}$. at $72^{\circ} \mathrm{C}$, after which a final DNA extension phase was carried out for $5 \mathrm{~min}$. at $72^{\circ} \mathrm{C}$. The amplified products were subjected to electrophoresis in $1.5 \%$ agarose gel stained with ethidium bromide.

\section{Acknowledgements}

We are indebted to Mr. Ariovaldo de Freitas from Fazenda Três Irmãs (Samua Comercial Ltda.), Araraquara, SP, Brazil, for providing the feathers of the animals. DNA Consult Genetics and Biotechnology S/C Ltda., São Carlos, SP, Brazil and the PIPE program from FAPESP supported this work.

\section{References}

I. Takagi N, Itoh M, Sasaki M: Chromosome studies in four species of Ratitae. Chromosoma 1972, 36:281-291

2. Ogawa A, Murata K, Mizuno S: The location of Z- and W-linked marker genes and sequence on the homomorphic sex chromosomes of the ostrich and the emu. Proceedings of the National Academy of Science of the USA 1998, 95(8):44I 5-44I8 
3. Bello N, Sánchez A: The identification of a Sex-specific DNA marker in the ostrich using a random amplified polymorphic DNA (RAPD) assay. Molecular Ecology 1999, 8(4):667-669

4. Griffiths R, Orr K: The use of amplified fragment length polymorphism (AFLP) in the isolation of sex-specific markers. Molecular Ecology 1999, 8(4):67I-674

5. Rudbek L, Dissing J: Rapid simple alkaline extraction of human genomic DNA from whole blood, buccal epithelial cells, semen and forensic stains for PCR. Biotechniques 1998, 25:588-592

6. Kimwele CN, Graves JA, Burke T, Hanote O: Development of microsatellite markers for parentage typing of chicks in the ostrich Struthio camelus. Molecular Ecology 1998, 7(2):249-25 |

7. Kumari P, Kemp SJ: Polymorphic microsatellite markers in the ostrich (Struthio camelus). Molecular Ecology 1998, 7:133-140

8. Ward WK, Mc Partlan HC, Matthews ME, Robinson NA: Ostrich microsatellite polymorphisms at the VIAS-OS4, VIAS-OS8, VIAS-OS22, and VIAS-OS29 loci. Animal Genetics 1998, 29(4):331

Publish with BioMed Central and every scientist can read your work free of charge

"BioMedcentral will be the most significant development for disseminating the results of biomedical research in our lifetime."

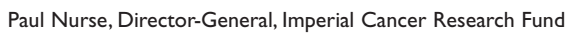

Publish with BMC and your research papers will be:

- available free of charge to the entire biomedical community

- peer reviewed and published immediately upon acceptance

- cited in PubMed and archived on PubMed Central

- yours - you keep the copyright

Submit your manuscript here:

http://www.biomedcentral.com/manuscript/
BioMedcentral.com editorial@biomedcentral.com 